\title{
A Research of the Impact of Corporate Internal Governance Structure on Earnings Management
}

\author{
Yuanyuan Li \\ Yunnan College of Business Management, Anning City, Yunnan Province, \\ 650304, China
}

\begin{abstract}
Earnings management is that enterprise managers choose accounting policies to achieve some specific objectives. It is an important issue that the stock market supervision department and investment institution pay close attention to and a project that the economics and accounting conduct extensive research about. In recent years, the ongoing fraud scandals have greatly harmed the interests of the majority of investors. In the final analysis, the defect of corporate governance structure is the main reason for the low quality of accounting information of listed companies in our country. Therefore, designing a perfect corporate internal governance structure will optimize the earnings management behavior. Based on the author's learning and practical experience, this paper first discussed concepts of corporate governance and earnings management and then analyzed the impact of corporate internal governance structure on earnings management. Finally, the article proposed countermeasures to strengthen earnings management.
\end{abstract}

Keywords: Governance structure; Earnings management; Impact; Suggestions

\section{Introduction}

With the establishment and improvement of the modern enterprise system in our country, earnings management problems caused by the corporate governance structure have been attracted more and more attention of all social parties[1]. At present, earnings management behavior has become one of the primary means to achieve corporate value. However, with this behavior intensifying, earnings fraud 
continues to occur. Seen from the existing literature, surplus after the management has reduced its information for users and this may mislead the parties to make wrong judgment and decisions to damage the optimization of resource allocation of the capital market. Therefore, the effectiveness of corporate governance will inevitably affect the earnings management behavior of the administering authority. This paper studies the relationship between earnings management and corporate governance structure and puts forward some countermeasures to improve the internal governance structure of Chinese companies with the hope to effectively control the earnings management behavior of listed companies in China[2].

\section{The Concepts of Corporate Governance Structure and Earnings Management}

Corporate governance structure refers to a set of institutional arrangements based on a relatively perfect market operation mechanism and internal control mechanism, which is formed to solve the principal-agent problem between the shareholders and the company by the construction of incentive and supervision mechanism for managers. The core of the corporate governance structure lies in the relationship between shareholders and managers. That is how shareholders effectively encourage and supervise managers in the separation of ownership and management rights, including internal governance structure and external governance structure. The relationship between the two governance mechanisms is that they can replace each other. However, each mechanism cannot play effective role fully, so they are complementary to each other. Effective corporate governance structure should solve two problems: first, give managers full freedom to manage the enterprise and shareholders can not do too much intervention; the second is to ensure that managers use the freedom to manage the enterprise for the interests of shareholders. It is that managers can get effective incentives and supervision. The former creates conditions for the managers to conduct earning management, while the latter stimulates the motive of managers' earnings management with compressing their earnings management space. We can see that there is a close relationship between corporate governance and earnings management. Corporate governance structure determines the motivation, behavior and economic consequences of earnings management and it will lead to changes in accounting information. 


\section{The Impact of Cooperate Internal Governance Structure on Earnings Management}

\subsection{The impact of corporate internal governance structure on earnings management}

The main participants of the cooperate internal governance structure include shareholder meeting, board of directors, managers and board of supervisors. From the perspective of principal-agent relationship, as the possessor, the shareholder has the ultimate control power; the board of directors is elected by the shareholder meeting and it is in full charge of the normal operation of the company. This leads to the first-level principal-agent relationship. Actually, managers are agents designated by the board of directors and they are responsible for the daily operations of the enterprise. This produces the second-tier principalagent relationship. The board of directors and the managers should be supervised and restrained by the board of supervisors. But this trusted relationship intensifies information asymmetry and increases difficulty of free flow of information. Undoubtedly, this also expands regular space for managers to conduct corporate earnings management[3]. Therefore, from the perspective of corporate internal governance structure, the objective and motivation of earnings management should naturally be to obtain satisfactory financial reports for shareholders with various legal means of earnings management, so as to clarify or cancel their own entrusted economic responsibility and give them rights to be commissioned.

\subsection{The impact of corporate external governance structure on earnings management}

First, the capital market. The capital market requires that managers of the enterprise need to disclose the financial status of the enterprise regularly and publicly, which makes the earnings management become an effective means to improve the business performance. They often use the traditional means of voluntary disclosure and other ways to provide and process information which is in their favor. They make efforts to reduce the company's financing costs in the capital market and improve profitability and market value of the corporate.

Second, the takeover market. Takeover market also refers to trading market of the corporate right of control and it is to collect shares or proxy to obtain control of the enterprise, so as to take over or replace managers. This approach is widely used in the highly developed capital markets, such as the Anglo-American model. The existence of the takeover market makes managers who are not performing well faced with the pressure of being taken over. This pressure also endows managers with the motive to use earnings management, so that they can not be taken over.

Third, the manager market. The existence of manager market means that there is a competition between agents. When managers' performance cannot satisfy the owner of the enterprise, the business owner have the right to replace the manager. As financial report provides an important indicator to evaluate business 
performance and an important standard to appraise managers' performance, the competition between the agents will affect the business performance of the corporate financial report[4]. The agent will use earnings management to make the corporate performance shown by the financial report maximize his market competitiveness.

Fourth, creditors governance. The binding effect of the corporate debts on corporate governance is from creditors, especially the supervision of banks and harsh debt provisions. In order to meet the requirements of creditors and avoid violating a series of harsh conditions signed with creditors, which may cause financial difficulties, business managers often use earnings management to manipulate business performance and deceive creditors.

\section{Suggestions on Strengthening Earnings Management}

\subsection{To make reasonable arrangements of the enterprise ownership}

The efficiency implication of the corporate governance structure is the symmetry distribution of the residual claim and control right. Therefore, we should clarify the property right and give full play to the property right system to standardize and define the generation process of accounting information. Clear definition of property rights makes it possible that stakeholders' goals tend to be accordant. To this end, the contract between them becomes more complete. This not only allows and encourages enterprises to choose accounting policies according to transaction costs, but also can give full play to the incentive-restriction and resource allocation function of accounting principles, so that it will reduce arbitrariness of accounting policy choice and reflect the common interests of enterprises as far as possible. For the status quo of our country, there still exist many problems: the property right in the ownership arrangement is still not clear enough; one share is in the dominant position; the proportion of outstanding shares is too small; insiders control shares. It is difficult to standardize the generation process of accounting information if the property right is not clear[5]. The unclear property right provides a convenient condition for the abuse of earnings management. Therefore, it is necessary to define property right and conduct reasonable institutional arrangements, reform and innovation.

\subsection{To establish an effective compensation contract}

The conflict of interests between the principal and the agent and the information asymmetry will cause ethical risk. In order to harmonize the two objectives, this kind of agency relationship usually presents as a series of contracts, especially the compensation plan contract. At present, the incentive of listed companies in China is mainly short-term payment motivation and the company lacks longterm incentive mechanism linked to the performance of the company. Therefore, we must design a reasonable compensation contract and introduce share option, option share and other new forms of compensation. To make the corporate 
management interests and business long-term interests link together will enable them to make accounting decisions from the company's highest interests. This will effectively safeguard the interests of other stakeholders, so as to effectively curb the occurrence of harmful earnings management behavior.

\subsection{To strengthen the supervision of the independent director}

The core of scientific corporate governance is to form a mutual cooperation and restriction mechanism between stakeholders by a specific governance structure and governance procedures. Guidelines for the Establishment of IDS of Listed Companies issued by China Securities Regulatory Commission (CSRC) requires that more than one third of directors in the board of listed companies should be independent directors, which should include at least one accounting professional. Code on Corporate Governance of Listed Companies promulgated by the CSRC formally proposed to set up an audit committee in the board of directors of listed companies[6]. Under the perfect corporate governance structure, the change of the accounting policies chosen by the enterprise and the earnings management should be supervised by independent directors and the audit committee. They should disclose the supervision to the relevant stakeholders. The stakeholders or independent directors have the right to require the management authority to explain or adjust the accounting policies. These measures will effectively strengthen the supervision of enterprise management.

\subsection{To form a contingent governance of earnings management}

The so-called contingent governance refers to that we should treat the business development in a dynamic way. The environment that enterprises face is constantly changing and the decision made by enterprise management authorities keep changing. The timing and methods of earnings management are also different. This requires that stakeholders' governance of earnings management must also be flexible. Stakeholders should build a dynamic enterprise contract network which must always be adjusted accordingly, especially to protect those who are most vulnerable to the interest loss. To maintain the contingent governance of earnings management, we believe that the most important thing is to form a competition of control rights in different interest bodies. In particular, we should break current closed pattern of control power in China. Specifically, when there are indications showing that the interests of governing subjects in the corporate are damaged, corporate stakeholders can immediately enter the appropriate contingent governance procedures and give full play to the mutual check-and-balance mechanism in mutual governance to reshuffle the enterprise[7]. They even can ask for a general meeting of shareholders, elect the board again or even replace the senior management in order to curb the misuse of earnings management to avoid harming the overall interests of enterprises. 


\section{Conclusion}

In recent years, although the study of earnings management has reached a certain level, people's understanding of the essence of earnings management is still not very clear, which shows the complexity of earnings management research. The earnings management research of this paper is limited to the perspective of corporate governance structure. However, it is unpractical to maximize the effect of earnings management from this perspective. In fact, the emergence and governance of earnings management is a comprehensive process, which needs joint efforts of effective regulation, institutional norms and the improvement of corporate governance.

\section{References}

[1] YU Zhuoping. A Study on the Relationship between Corporate Governance and Earnings Management.Communication of Finance and Accounting, 06, PP.85-87, 2011.

[2] Lin Zhonggao, Xu Zhenggang. A Research of the Impact of Earnings Management from the Perspective of Corporate Governance Structure. Finance and Economics, 04, pp.57-62, 2002.

[3] Wang Lixian.A Study on the Impact of Listed Appliance Company Governance on Earnings Management. Shanxi Finance and Tax, 2016, 02: 49-50.

[4] Wang Shengnian, Bai Jun.An Empirical Study on the Impact of Corporate Governance on Earnings Management. Journal of Shihezi University (Social Science Edition),03, pp.43-46, 2009.

[5] Wang Hong, Mao Daowei and Li Heng. An Empirical Study on the Impact of Corporate Governance on Earnings Management. Journal of Sichuan University (Social Science Edition), 06, pp.66-74, 2009.

[6] Liu Weisong, Zhou Zhuohua and Zhang Zongyi. A Game Analysis of Earnings Management in Corporate Governance Structure. Finance and Trade Research, 02, pp.104-108, 2005.

[7] Chen Lijun. A Study of the Governance Tactics of Earnings Management in Listed Companies. Journal of Dalian Maritime University (Social Science Edition), 04, pp.52-56, 2008. 